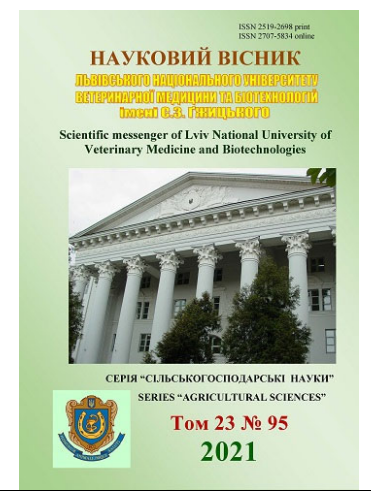

UDC 606:637.3:637.055
Науковий вісник Дьвівського національного університету ветеринарної медицини та біотехнодогій імені С.3. Гжицького. Серія: Сільськогосподарські науки

\author{
Scientific Messenger of Lviv National University \\ of Veterinary Medicine and Biotechnologies. \\ Series: Agricultural sciences
}

ISSN 2519-2698 print ISSN 2707-5834 online doi: 10.32718/nvlvet-a9503

https://nvlvet.com.ua/index.php/agriculture

\title{
Influence of enterococci on the sensitivity of opportunistic microflora to antibiotics
}

\author{
I. I. Kushnir ${ }^{1}$, I. S. Semen ${ }^{2}$, O. Y. Tsisaryk ${ }^{1}$, I. M. Kushnir ${ }^{2}$ \\ ${ }^{1}$ Stepan Gzhytskyi National University of Veterinary Medicine and Biotechnologies Lviv, Ukraine \\ ${ }^{2}$ State Scientific-Research Control Institute of Veterinary Medicinal Products and Feed Additives, Lviv, Ukraine
}

Article info

Received 09.04.2021

Received in revised form 12.05 .2021

Accepted 13.05.2021

Stepan Gzhytskyi National University of Veterinary Medicine and Biotechnologies, Pekarska Str., 50, Lviv, 79010, Ukraine. Tel.: +38-098-290-16-94 E-mail: irynakushn@gmail.com

State Scientific-Research Control Institute of Veterinary Medicinal Products and Feed Additives, Donetska Str., 11, Lviv, 79019, Ukraine.
Kushnir, I. I., Semen, I. S., Tsisaryk, O. Y., \& Kushnir, I. M. (2021). Influence of enterococci on the sensitivity of opportunistic microflora to antibiotics. Scientific Messenger of Lviv National University of Veterinary Medicine and Biotechnologies. Series: Agricultural sciences, 23(95), 2528. doi: $10.32718 /$ nvlvet-a9503

The article presents the results of determining the ability of enterococci isolated from traditional Carpathian cheese to affect the antibiotic sensitivity of opportunistic gram-positive and gram-negative microorganisms, particularly test strains of S. aureus and E. coli. It was found that enterococci had different effects on the sensitivity of opportunistic pathogens to different groups of antimicrobial drugs. In particular, cocultivation of S. aureus with enterococci did not affect the change in sensitivity to amoxicillin and glycopeptides (vancomycin). In the study of aminoglycosides, it was found that the sensitivity of staphylococcus to gentamicin increased when co-cultured with strains of E. faecium SB12 and E. durans SB18 by $14.8(P<$ $0.05)$ and $13.1 \%(P<0.01)$, respectively. The tendency to increase the sensitivity of staphylococcus to streptomycin was also observed in cultivation with E. faecium SB12 and E. durans SB18. Concerning macrolides, in particular erythromycin, only one strain of E. durans SB18 caused a $3.2 \%$ increase in staphylococcal susceptibility, and a probable increase in staphylococcal susceptibility was found in fluoroquinolones. In particular, the sensitivity of staphylococci to enrofloxacin and norfloxacin increased by 7.6 and $5.3 \%$, respectively $(P<0.05)$. The antibiotic susceptibility of E. coli with enterococci found a slight increase in sensitivity to penicillins when co-cultured with strains of E. faecium SB12 and E. durans SB18. Thus, the antibiotic sensitivity of E. coli increased by 5.1 and $7.5 \%$, respectively. In addition, the sensitivity of E. coli to aminoglycosides (streptomycin) increased under co-cultivation with E. durans SB6 and SB18 strains by 7,5 , and $9.7 \%$, respectively $(P<0.05)$. In addition, when co-cultured with E. faecium $S B 12$ and E. durans SB18 strain, the sensitivity of E. coli to enrofloxacin increased by 7.6 and $5.3 \%$, respectively $(P<0.05)$, and to norfloxacin - by 3, 8, and 4.9\%. Co-cultivation with E. durans SB6 and E. faecium SB12 strains increased the sensitivity of E. coli to B-lactam antibiotics, in particular, cefazolin by $9.1 \%(P<$ $0.05)$, and in co-cultivation with E. durans $S B 18-$ at $14.1 \%(P<0.01)$.

Key words: Enterococcus durans, E. faecium, antibiotics, susceptibility, cultivation, opportunistic pathogens.

\section{Вплив ентерококів на чутливість умовно-патогенної мікрофлори до антибіотиків}

\author{
I. I. Кушнір ${ }^{1}$, I. С. Семен ${ }^{2}$, О. Й. Цісарик ${ }^{1}$ I. М. Кушнір ${ }^{2}$ \\ ${ }^{1}$ Львівський націіональний університет ветеринарної медицини та біотехнологій імені С. 3. Гжсицького, м. Львів, \\ Україна \\ ${ }^{2}$ Державний науково-дослідний контрольний інститут ветеринарних препаратів та кормових добавок, \\ м. Львів, Україна
}


У статті наведено результати визначення здатності ентерококів, виділених з традиційної карпатської бринзи, впливати на антибіотикочутливість умовно-патогенних грампозитивних та грамнегативних мікроорганізмів, зокрема тест-цтамів S. аитеи та E. coli. Було встановлено, щуо ентерококи по-різному впливали на підвищення чутливості умовно-патогенної мікрофлори до різних груп протимікробних препаратів. Зокрема, сумісне культивування S. аигеиs з ентерококами не впливало на зміну чутливості до амоксиииліну та глікопептидів (ванкоміцину). При дослідженні аміноглікозидів встановили, що чутливість стафілококу до гентаміцину зростала за умови спільного культивування із штамами E. fаесіит SB12 ma E. durans SB18 відповідно на 14,8 $(P<0,05)$ та 13,1\% (P<0,01). Тенденцію до підвищення чутливості стафілококу до стрептоміцину відзначали також при культивуванні із E. faecium SB12 та E. durans SB18. Щодо макролідів, зокрема еритроміцину, тільки один итам E. dигапs SB18 спричинював підвищення чутливості стафілококу на 3,2 \%, а вірогідне підвищення чутливості стафілококу встановили до фторхінолонів. Зокрема, чутливість стафілококу до енрофлоксацину та норфлоксацину підвищувалась відповідно на 7,6 та 5,3 \% (P < 0,05). При вивченні антибіотикочутливості E. coli з ентерококами встановили незначне підвищення чутливості до пеніцилінів за сумісного культивування із штамами E. faеcium SB12 та E. durans SB18. Так, антибіотикочутливість E. соli підвищувалась відповідно на 5,1 та 7,5\%. Також чутливість E. coli до аміноглікозидів (стрептоміцину) зростала за умови спільного культивування із штамами E. durans SB6 та SB18 відповідно на 7, 5 та 9,7\% (P < 0,05). Крім того, за спільного культивування із итамом Е. fаесіит SB12 та E. durans SB18 чутливість E. coli до енрофлоксацину підвищувалась відповідно на 7,6 та 5,3\% (P < 0,05), а до норфлоксацину - відповідно на 3,8 та 4,9\%. Спільне культивування зі штамами E. durans SB6 та E. fаесіит SB12 сприяло підвищенню чутливості E. coli до ß-лактамних антибіотиків, зокрема цеефазоліну на 9,1\% (P<0,05), а при спільному культивуванні із Е. диrans $S B 18-$ на $14,1 \%(P<0,01)$.

Ключові слова: Enterococcus durans, E. faеcium, антибіотики, чутливість, культивування, умовно-патогенна мікрофлора.

\section{Вступ}

Сьогодні особлива увага провідних фахівців приділяється застосуванню пробіотиків, що пов'язано зі зниженням ефективності антибіотикотерапії та збільшенням частоти побічних реакцій при використанні антимікробних препаратів. Однак за використання таких препаратів $є$ загроза поширення генів антибіотикостійкості як при кон'югації, так і інших механізмах, зокрема трансформації або трансдукції (Oryshak et al., 2013; Kushnir et al., 2020). Важливою перевагою пробіотиків 3 властивим їм широким спектром антагоністичної активності щодо патогенних та умовнопатогенних мікроорганізмів $є$ те, що на відміну від антибіотиків вони не викликають утворення до них стійких форм бактерій (Dinleyici et al., 2013; Vitetta et al., 2014; Musiy et al., 2017) і не пригнічують імунітету, а стимулюють вироблення антитіл і його неспецифічних факторів (Serebryakova, 2014; Ashraf \& Shah, 2014; Kushnir et al., 2015). Штами, призначені для використання як пробіотики або бактеріальні закваски, не повинні мати вірулентних детермінантів, мають бути чутливими до антибіотиків і при цьому володіти добрими функціональними та технологічними властивостями (Franz, 2003).

Оскільки ентерококи можуть проявляти як патогенні, так і пробіотичні властивості, вони повинні бути добре охарактеризовані та оцінені 3 огляду їхньої безпечності. Надзвичайно важливим є розмежування патогенних та безпечних ентерококів з метою оцінювання їх як потенційних пробіотичних штамів. Використання таких штамів повинно враховувати раціональне застосування антибіотиків у гуманній та ветеринарній медицині (Braiek \& Smaoui, 2019).

3 огляду на це метою нашої роботи було вивчити вплив ентерококів E. durans SB6, E. faecium SB12, E. durans SB18, E. durans SB20, виділених із традиційної карпатської бринзи (Slyvka et al., 2018) за сумісного культивування 3 умовно-патогенними мікрооранізмами на чутливість останніх до антибіотиків.

\section{Матеріал і методи досліджень}

Для проведення досліджень 3 визначення чутливості умовно-патогенної мікрофлори до антибіотиків застосовували метод дифузії в агар із використанням стандартних паперових дисків з антибіотиками. Цей метод базується на здатності антибіотика дифундувати в агарове середовище і перешкоджати розмноженню культури, що призводить до утворення прозорих зон гальмування їхнього росту. Результати враховували за величиною зони затримки росту мікроорганізмів навколо дисків. За допомогою лінійки вимірювали діаметр зони затримки росту довкола дисків, включаючи самі диски (Avdyeyeva et al., 2005). Перед проведенням спільного культивування тест-культур $S$. aureus та $E$. coli iз різними штамами ентерококів визначили чутливість тест-штамів до антибактеріальних препаратів. Спільне культивування проводили в м'ясо-пептонному бульйоні упродовж трьох діб. Культури дослідних штамів ентерококів і тест-мікробів готували в однакових умовах росту, при цьому провели попередню адаптацію до поживних середовищ шляхом 2-3 пасажів. Після чого готували завись мікроорганізмів за оптичним стандартом Мак Фарланда iз розрахунку $1,5 \times 10^{8} \mathrm{KУO} / \mathrm{cm}^{3}$ та вносили окремо культури ентерококів та тест-штамів мікроорганізмів у пробірки із $9 \mathrm{~cm}^{3}$ МПБ у кількості: ентерококи $1 \mathrm{~cm}^{3}$ а тест-штами $S$. aureus та $E$. coli $-0,5 \mathrm{~cm}^{3}$.

Після спільного культивування проводили виділення чистої тест-культури мікроорганізмів, шляхом висівання на відповідні селективні живильні середовища для кожної культури та проводили визначення чутливості тест-штамів $S$. aureus та $E$. coli до антибіотиків.

\section{Результати та їх обговорення}

Чутливість $S$. aureus до антимікробних препаратів після спільного тридобового культивування із досліджуваними ентерококами наведено у таблиці 1. Як видно з результатів досліджень, сумісне культивування S. aureus 3 ентерококами не впливало на зміну чутливості до пеніцилінів, зокрема, амоксициліну. При дослідженні аміноглікозидів встановили, що 
чутливість стафілококу до гентаміцину зростала за умови спільного культивування зі штамами $E$. faecium SB12 та E. durans SB18 віповідно на $14,8(\mathrm{P}<0,05)$ та $13,1 \%(\mathrm{P}<0,01)$. Тенденцію до підвищення чутливості стафілококу до стрептоміцину виявляли також при культивуванні $з$ E. faecium SB12 та E. durans SB18. Щодо макролідів, зокрема еритроміцину, тільки один штам E. durans SB18 спричинював підвищення чутливості стафілококу на 3,2 \%. Вірогідне підвищення чутливості стафілококу до фторхінолонів спостерігали за спільного культивування із штамом E. durans
SB18. Зокрема, чутливість стафілококу до енрофлоксацину та норфлоксацину підвищувалась відповідно на 7,6 та 5,3\% ( $<<0,05)$. До Љ-лактамних антибіотиків, зокрема цефазоліну, спільне культивування із штамами E. faecium SB12 та E. durans SB18 сприяло підвищенню чутливості стафілококу відповідно на 13,5 та $16,4 \%(\mathrm{P}<0,01)$.

Впливу досліджуваних штамів на чутливість стафілококу до глікопептидів, зокрема ванкоміцину, не виявили.

\section{Таблиця 1}

Вплив ентерококів на чутливість $S$. aureus до антибіотиків $(\mathrm{M} \pm \mathrm{m}, \mathrm{n}=3)$

\begin{tabular}{|c|c|c|c|c|c|}
\hline \multirow{2}{*}{ Антибіотики } & \multirow{2}{*}{$\begin{array}{c}\text { S. aureus } \\
\text { до спільного } \\
\text { культивування }\end{array}$} & \multicolumn{4}{|c|}{ S. aureus після спільного культивування з: } \\
\hline & & E. durans SB6 & E. faecium SB 12 & E. durans SB18 & E. durans SB20 \\
\hline Амоксицилін & $24,3 \pm 0,3$ & $24,3 \pm 0,3$ & $23,3 \pm 0,3$ & $24,3 \pm 0,3$ & $23,6 \pm 0,3$ \\
\hline Оксацилін & $23,3 \pm 0,3$ & $23,6 \pm 0,3$ & $22,6 \pm 0,3$ & $23,3 \pm 0,3$ & $23,3 \pm 0,3$ \\
\hline Гентаміцин & $20,3 \pm 0,3$ & $18,3 \pm 0,3$ & $23,6 \pm 0,3 * *$ & $23,3 \pm 0,3 *$ & $19,3 \pm 0,3$ \\
\hline Стрептоміцин & $15,6 \pm 0,3$ & $15,3 \pm 0,3$ & $16,3 \pm 0,3$ & $16,6 \pm 0,3$ & $15,6 \pm 0,3$ \\
\hline Канаміцин & $17,3 \pm 0,3$ & $16,6 \pm 0,3$ & $17,3 \pm 0,3$ & $18,3 \pm 0,3$ & $16,6 \pm 0,3$ \\
\hline Еритроміцин & $21,6 \pm 0,3$ & $20,6 \pm 0,3$ & $21,6 \pm 0,3$ & $22,3 \pm 0,3$ & $20,6 \pm 0,3$ \\
\hline Тилозин & $23,3 \pm 0,3$ & $22,6 \pm 0,3$ & $21,6 \pm 0,3^{*}$ & $23,3 \pm 0,3$ & $21,6 \pm 0,3^{*}$ \\
\hline Тетрацин & $22,3 \pm 0,3$ & $22,6 \pm 0,3$ & $22,6 \pm 0,3$ & $23,3 \pm 0,3$ & $22,6 \pm 0,3$ \\
\hline Доксициклін гідрохлорид & $23,3 \pm 0,3$ & $23,6 \pm 0,3$ & $24,3 \pm 0,3$ & $24,6 \pm 0,3 *$ & $23,6 \pm 0,3$ \\
\hline Енрофлоксацин & $26,3 \pm 0,3$ & $26,6 \pm 0,3$ & $27,3 \pm 0,3$ & $28,3 \pm 0,3 *$ & $27,3 \pm 0,3$ \\
\hline Норфлоксацин & $24,3 \pm 0,3$ & $25,3 \pm 0,3$ & $25,3 \pm 0,3$ & $25,6 \pm 0,3^{*}$ & $24,6 \pm 0,3$ \\
\hline Цефалексин & $21,6 \pm 0,3$ & $22,3 \pm 0,3$ & $22,6 \pm 0,3$ & $25,6 \pm 0,3 * *$ & $23,3 \pm 0,3 *$ \\
\hline Цефазолін & $24,3 \pm 0,3$ & $24,3 \pm 0,3$ & $27,6 \pm 0,3 * *$ & $28,3 \pm 0,3 * *$ & $24,3 \pm 0,3$ \\
\hline Нітрофураратоїн & $21,6 \pm 0,3$ & $20,6 \pm 0,3$ & $20,3 \pm 0,3 *$ & $22,3 \pm 0,3$ & $21,3 \pm 0,3$ \\
\hline Левоміцетин & $18,3 \pm 0,3$ & $20,3 \pm 0,3 *$ & $20,6 \pm 0,3 * *$ & $21,3 \pm 0,3 * *$ & $19,3 \pm 0,3$ \\
\hline Ванкоміцин & $15,3 \pm 0,3$ & $15,6 \pm 0,3$ & $15,6 \pm 0,3$ & $16,3 \pm 0,3$ & $16,3 \pm 0,3$ \\
\hline Поліміксин В & $9,6 \pm 0,3$ & $10,3 \pm 0,3$ & $10,6 \pm 0,3$ & $11,3 \pm 0,3^{*}$ & $10,6 \pm 0,3$ \\
\hline Рифампіцин & $25,6 \pm 0,3$ & $25,3 \pm 0,3$ & $27,3 \pm 0,3 *$ & $27,3 \pm 0,3 *$ & $26,3 \pm 0,3$ \\
\hline
\end{tabular}

Примітка: *- ${ }^{*}<0,05, * *-\mathrm{P}<0,01$

Таблиця 2

Вплив ентерококів на чутливість $E$. coli до антибіотиків $(\mathrm{M} \pm \mathrm{m}, \mathrm{n}=3)$

\begin{tabular}{|c|c|c|c|c|c|}
\hline Антибіотики & $\begin{array}{c}E . c o l i \\
\text { до спільного } \\
\text { культивування }\end{array}$ & E. durans SB6 & E. faecium SB 12 & E. durans SB18 & E. durans SB20 \\
\hline Амоксицилін & $13,6 \pm 0,3$ & $13,6 \pm 0,3$ & $14,3 \pm 0,3$ & $14,6 \pm 0,3$ & $13,6 \pm 0,3$ \\
\hline Оксацилін & - & - & - & - & - \\
\hline Гентаміцин & $18,3 \pm 0,3$ & $19,3 \pm 0,3$ & $18,3 \pm 0,3$ & $18,7 \pm 0,3$ & $18,3 \pm 0,3$ \\
\hline Стрептоміцин & $13,3 \pm 0,3$ & $14,6 \pm 0,3^{*}$ & $13,3 \pm 0,3$ & $14,3 \pm 0,3$ & $13,6 \pm 0,3$ \\
\hline Канаміцин & $17,3 \pm 0,3$ & $15,7 \pm 0,3^{*}$ & $17,7 \pm 0,3$ & $17,7 \pm 0,3$ & $15,3 \pm 0,3^{*}$ \\
\hline Еритроміцин & $8,6 \pm 0,3$ & $7,3 \pm 0,3^{*}$ & $9,3 \pm 0,3$ & $8,3 \pm 0,3$ & $9,3 \pm 0,3$ \\
\hline Тетрациклін & $20,3 \pm 0,3$ & $19,6 \pm 0,3$ & $21,7 \pm 0,3^{*}$ & $20,6 \pm 0,3$ & $18,7 \pm 0,3^{*}$ \\
\hline Доксициклін гідрохлорид & $15,3 \pm 0,3$ & $16,3 \pm 0,3$ & $18,3 \pm 0,3 * *$ & $17,6 \pm 0,3 * *$ & $18,3 \pm 0,3 * *$ \\
\hline Енрофлоксацин & $26,3 \pm 0,3$ & $26,7 \pm 0,3$ & $28,6 \pm 0,3^{* *}$ & $28,6 \pm 0,3 * *$ & $26,6 \pm 0,3$ \\
\hline Норфлоксацин & $26,3 \pm 0,3$ & $27,3 \pm 0,3$ & $27,3 \pm 0,3$ & $27,6 \pm 0,3 *$ & $26,3 \pm 0,3$ \\
\hline Цефалексин & $14,3 \pm 0,3$ & $14,3 \pm 0,3$ & $14,7 \pm 0,3$ & $14,7 \pm 0,3$ & $14,3 \pm 0,3$ \\
\hline Цефазолін & $18,7 \pm 0,3$ & $20,3 \pm 0,3^{*}$ & $20,3 \pm 0,3^{*}$ & $21,3 \pm 0,3 * *$ & $18,7 \pm 0,3$ \\
\hline Нітрофураратоїн & $19,3 \pm 0,3$ & $19,3 \pm 0,3$ & $20,7 \pm 0,3^{*}$ & $21,3 \pm 0,3^{*}$ & $19,6 \pm 0,3$ \\
\hline Левоміцетин & $21,3 \pm 0,3$ & $20,6 \pm 0,3$ & $20,7 \pm 0,3$ & $21,3 \pm 0,3$ & $21,3 \pm 0,3$ \\
\hline Ванкоміцин & $17,3 \pm 0.3$ & $18,3 \pm 0,3$ & $19,3 \pm 0,3^{*}$ & $17,7 \pm 0,3$ & $16,6 \pm 0,3$ \\
\hline Поліміксин В & $14,3 \pm 0,3$ & $14,7 \pm 0,3$ & $14,3 \pm 0,3$ & $14,7 \pm 0,3$ & $14,3 \pm 0,3$ \\
\hline Рифампіцин & $16,3 \pm 0,3$ & $15,6 \pm 0,3$ & $16,3 \pm 0,3$ & $16,6 \pm 0,3$ & $17,3 \pm 0,3$ \\
\hline
\end{tabular}

Примітка: *-P $<0,05, * *-\mathrm{P}<0,01$

Результати визначення чутливості E. coli до антимікробних препаратів після спільного тридобового культивування із досліджуваними ентерококами на- ведено у таблиці 2. Сумісне культивування E. coli 3 ентерококами спричинювало незначне підвищення чутливості до пеніцилінів, зокрема амоксициліну. 
Так, чутливість E. coli після сумісного культивування із штамами E. faecium $\mathrm{SB} 12$ та $E$. durans $\mathrm{SB} 18$ підвищувалась відповідно на 5,1 та 7,5 \%. Чутливість $E$. coli до аміноглікозидів, зокрема стрептоміцину, зростала за умови спільного культивування зі штамами $E$. $d u$ rans SB6 та SB18 відповідно на 7,5 та 9,7 \% (P < 0,05). Вірогідне підвищення чутливості E. coli до фторхінолонів спостерігали за спільного культивування зі штамом E. faecium SB 12 та E. durans SB18. Зокрема, чутливість $E$. coli до енрофлоксацину підвищувалась відповідно на 7,6 та 5,3 \% (Р < 0,05), а до норфлоксацину - відповідно на 3,8 та 4,9 \%. Щодо ßлактамних антибіотиків, зокрема цефазоліну, спільне культивування із штамами $E$. durans SB6 та E. faecium SB12 сприяло підвищенню чутливості E. coli на 9,1\% (P < 0,05), а при спільному культивуванні з E. durans SB18 - на $14,1 \%$ ( $<<0,01)$. Крім того, встановили підвищення чутливості до ванкоміцину E. coli на $11 \%$ $(\mathrm{P}<0,01)$ за iї спільного культивування із штамом E. faecium SB12.

\section{Висновки}

1. Виділені з традиційної карпатської бринзи ентерококи по - різному впливали на чутливість умовнопатогенної мікрофлори до різних груп протимікробних препаратів.

2. Серед виділених із традиційної карпатської бринзи ентерококів штам $E$. durans $S B 18$ проявляв більш виражений вплив на підвищення чутливості тест-штамів $S$. aureus та E. coli до більшості досліджуваних антибіотиків.

Відомості про конфлікт інтересів. Автори стверджують про відсутність конфлікту інтересів щодо їхього вкладу та результатів досліджень.

\section{References}

Ashraf, R., \& Shah, N. P. (2014). Immune system stimulation by probiotic microorganisms. Crit. Rev. Food Sci. Nutr, 54(7), 938-956. doi: 10.1080/10408398.2011.619671.

Avdyeyeva, L. V., Polishchuk, O. I., \& Pokas, O. V. (2005). Metodolohichni pidkhody do vyznachennya chutlyvosti mikrorhanizmiv do antybiotykiv. Laboratorna diahnostyka, 3(33), 35-40 (in Ukrainian).

Braiek, O. B., \& Smaoui, S. (2019). Enterococci: Between Emerging Pathogens and Potential Probiotics.
BioMed Research International, 2019, 5938210. doi: $10.1155 / 2019 / 5938210$.

Dinleyici, E. C., Dalgic, N., Guven, S., Ozen, M., Kara, A., Arica, V., Metin-Timur, O., Sancar, M., Kurugol, Z., Tanir, G., Ozturk, D., Aydogdu, S., Tutanc, M., Eren, M., \& Vandenplas, Y. (2013). The effect of a multispecies synbiotic mixture on the duration of diarrhea and length of hospital stay in children with acute diarrhea in Turkey: Single blinded randomized study. Eur. J. Pediatr, 172(4), 459-464. doi: 10.1007/s00431-012-1903-5.

Franz, C. (2003). Enterococci in foods-a conundrum for food safety. International Journal of Food Microbiology, 88(2-3), 105-122. doi: 10.1016/s01681605(03)00174-0.

Kushnir, I. M., Semen, I. S., \& Mayba, U. Z. (2015). Vyvchennya biolohichnykh vlastyvostey probiotychnykh shtamiv mikroorhanizmiv. Nauk.tekhn. byul. DNDKI vetpreparativ ta kormovykh dobavok ta Instytutu biolohiyi tvaryn, 16(2), 207-212 (in Ukrainian).

Kushnir, I., Tsisaryk, O., Shalovylo, S., Gutyj, B., Kushnir, G., Slyvka, I., \& Musiy, L. (2020). The ability of enterococci extracted from traditional Carpathian cheese bryndza to produce biologically active substances. Ukrainian Journal of Veterinary and Agricultural Sciences, 3(3), 15-19. doi: 10.32718/ujvas3-3.03.

Musiy, L., Tsisaryk, O., Slyvka, I., Mykhaylytska, O., \& Gutyj, B. (2017). Research into probiotic properties of cultured butter dur-ing storing. Eastern-European Journal of Enterprise Technolo-gies, 3(11(87), 31-36. doi: 10.15587/1729-4061.2017.103539.

Oryshak, E. A., Shchehlov, V. S., \& Shylova, L. Yu. (2013). Sravnytelnaya kharakterystyka antybyotykorezystentnosty nekotorykh predstavyteley mykrobyotov kyshechnyka y probyotycheskykh shtammov. Problemy meditsinskoy mikolohii, 4, 7480 (in Russian).

Serebryakova, E. N. (2014). Probiotics for Prevention and Treatment at Diarrhea in Children. The difficult patient, 12(5), 20-25.

Slyvka, I. M., Tsisaryk, O. Y., Dronyk, G. V., \& Musiy, L. Y. (2018). Strains of lactic acid bacteria isolated from traditional Carpathian cheese. Regulatory Mechanisms in Biosystems, 9(1), 62-68. doi: 10.15421/021808.

Vitetta, L., Briskey, D., Alford, H., Hall, S., \& Coulson, S. (2014). Probiotics, prebiotics and the gastrointestinal tract in health and disease. Inflammopharmacology, 22(3), 135-154. doi: 10.1007/s10787-014-0201-4. 